\title{
Reflexions on energy balance
}

\section{By R. PASSMORE, Io Mansionhouse Road, Edinburgh $E H_{9}$ I $T Z$}

Calorimetry is the basis of the science of nutrition, a statement I first saw as the title of a paper by the chief of the department of medicine at the Mayo Foundation (Wilder, 1959). Our science began when Lavoisier put a guinea pig into a calorimeter, measured the amount of ice melted and showed that this was quantitatively related to the amount of fixed air or carbon dioxide given off by the animal. Measurement of the respiratory exchanges (indirect calorimetry) has always been technically much easier than measurement of heat loss. Systematic study of energy exchanges in man began in 1866 in Munich where Pettenkofer and Voit had constructed a respiration chamber suitable for man. This they were able to do through the patronage of King Maximillian II of Bavaria. Pettenkofer was a colourful personality who had been appointed professor of dietetic chemistry in 1847 at Munich, where later he founded the first Institute of Hygiene. It was there most of the fathers of nutrition came for postgraduate study under Voit, his distinguished assistant and successor. The American W.O. Atwater, after studying at Munich returned home and with the help of an engineer, Rosa, built the first calorimeter for human subjects. Rubner, another of Voit's pupils, played a major part in determining the energy value of human foods. When in 1906 Graham Lusk, also a pupil of Voit, wrote the first edition of The Science of Nutrition (Lusk, rgo6) he was able to set out the principles of the energy exchanges in man, and these appear substantially unchanged today in undergraduate textbooks of physiology and nutrition. I am grateful to my Oxford tutor, Dr Kenneth Franklin, that he told me to read Lusk's book during a long vacation. Thanks to the initiative of Bill Darby, the American Nutrition Foundation has reprinted Lusk's book. I suggest that you recommend it to those of your students who have the capacity to read.

In the first half of the 2oth century the interest of nutritionists was diverted from the study of energy by the discovery of vitamins. It was revived in World War II by food shortages and problems of rationing in the combatant countries and by the appalling starvation in many prisons and concentration camps. Ancel Keys and his colleagues at the University of Minnesota in $195^{\circ}$ published The Biology of Human Starvation, which not only describes their famous experiments on partial starvation, but also contains a full review of the literature and of contemporary thinking on the subject.

The end of World War II did not see the end of rationing in the United Kingdom. Indeed bread was rationed for the first time in 1946 . This was because so many ships had been sunk that not enough remained to carry across the Atiantic the foods and goods needed to rehabilitate the health of the people and of the A speech given after the Meeting Dinner on Thursday, i 7 th September. 
industries of continental Europe. Rationing and other food restrictions continued until 1952. In retrospect the fact that we, a militarily victorious people, put up with this austerity, though not without much grumbling, for the benefit of defeated nations is a remarkable example of altruism on a national scale, and all of us should ponder on this fact when considering the great political problems of today.

In the post-war climate of opinion the Medical Research Council set up a diet and energy committee. R. C. Garry, professor of physiology at Glasgow, a pupil of Cathcart who was a pupil of Voit, was chairman and I was secretary. G. C. Douglas, of Douglas bag fame, was a member. A chance friendship now played an important part in my life. My wife and I had made friends with Dr and Mrs Hugh Magee in 1935 while travelling down the Volga on a steamship, after attending the International Physiology Congress in Leningrad. After the war Magee was in Germany on behalf of our government and he procured from the Institut für Arbeitsphysiologie in Dortmund, a Kofranyi-Michaelis respirometer. This instrument made indirect calorimetry practical under field conditions. Previously only Douglas bags had been used and they are too cumbersome for most field studies. The Dortmund workers had used the new respirometer in widespread studies of energy expenditure in industry in wartime Germany (Lehmann et al. 1950) and the information obtained was used by the authorities in determining ration scales for industrial workers. Hugh Magee gave the respirometer to me to try out in the laboratory. When I reported that it was a reliable instrument, the diet and energy committee suggested that it might be used to measure for the first time the energy expenditure of leisure and off-work activities, and so make possible the recording of the energy balance in people outside the artificial laboratory conditions in which Atwater had had to constrain his subjects.

Two major surveys followed upon the deliberations of the committee in which both the energy intake and energy output were measured for a period of a week in people living their normal everyday life. The subjects were Sandhurst military cadets (Widdowson et al. 1954) and miners and colliery clerks in Fife (Garry et al. 1955). These surveys led to considerations of energy utilization, both at work and in leisure activities, in recommendations of energy requirements for the population and this approach was adopted internationally when the FAO report on Calorie Requirements, first published in $195^{\circ}$, was revised in 1957 and again in 1973.

Before the Sandhurst and Fife surveys, a pilot study was made on five medical students whilst they led a partially controlled life during vacation, feeding and sleeping in the Usher Institute (Department of Social Medicine, Edinburgh). Fig. I has been taken from the paper reporting this study (Passmore et al. 1952). It has two important messages. First it shows that what seems a major disaster in an experiment may turn out to be a valuable opportunity for new observation. When, after the experiment had been running for $6 \mathrm{~d}$, one subject, John, developed mumps, I was in a fix. No Edinburgh hospital would admit a patient with mumps. John's landlady in Edinburgh was a friend of mine and I could not send back to her a lodger who would infect her four young children. His home was in England and British Railways and their passengers would not have looked kindly on someone 


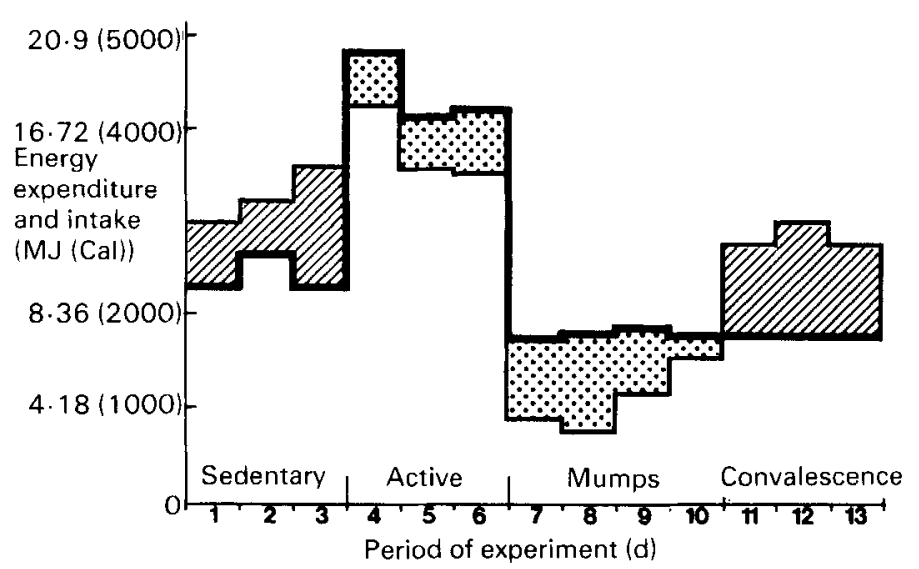

Fig. I. Energy balance of a young man. (-) Daily energy intake, (-) daily energy expenditure, (国) excess intake over expenditure, (圈) excess expenditure over intake.

with obvious mumps trying to board a train. The only possible solution was to put up a bed for John in my office. Then we decided to go on with the measurements of the energy exchanges under the new conditions. Finally we had records on him for $13 \mathrm{~d}$ on none of which was he in energy balance, but over the whole period his food provided $36280 \mathrm{kcal}$ and his energy expenditure was estimated at 34310 . The difference, on average $150 \mathrm{kcal} / \mathrm{d}$, is within the error of measurement.

Subsequent analysis of the Sandhurst, Fife and other results (Durnin, I96I) has shown conclusively that men and women do not normally adjust food intake and physical activity so as to be in energy balance each day though most of them do so over a week. A deficit or excess of $12.6 \mathrm{MJ}(3000 \mathrm{kcal})$, the equivalent of a whole day's food intake, is commonplace. At a personal level this is well illustrated by Nan Taggart's records of her own food intake and body-weight over 80 consecutive d (Taggart, I962), one of the most elegant papers ever to have appeared in our journal.

I came to nutrition as a physiologist brought up on the works of Claude Bernard and Walter Cannon and their conceptions of the constancy of the internal environment and of homoeostasis. These masters were concerned with regulatory measures for controlling blood glucose, body temperature and other factors that depend on minute by minute or even second by second adjustments of the blood flow and metabolism of individual organs or systems of the body. They were not concerned with long term regulatory mechanisms. Energy balance and the maintenance of appropriate stores of nutrients are not the only examples of these. There are also the changes in body composition and function that occur in pregnancy. Physiologists in general have not yet got down to these problems. In modern textbooks of physiology the unit of time is usually the minute or second and frequently the millisecond, sometimes the hour or the day, but only rarely the 
week, the month or the year. We have not been trained conceptually to consider long term regulation mechanisms.

\section{Present studies on energy balance}

Much of the work on energy today is related to two human disorders, anorexia nervosa and obesity, and innumerable studies have been made on the metabolism of patients. I continue to be impressed by how little the findings differ from those in normal subjects. There is also the perennial problem of how some of us appear to eat like horses and yet remain thin, whilst others, if they do not continually exercise conscious restraint on their food intake, readily put on excess weight. It is postulated that the thin people keep thin because they operate thermodynamically inefficient metabolic pathways or futile cycles, and that these are concentrated especially in brown adipose tissue. I have no enthusiasm for these views. BAT is now established as having a major role in the regulation of body temperature in young mammals including newborn infants who cannot shiver. This was a major advance in understanding of one physiological control mechanism, but the regulation of body temperature and body-weight are very different problems and not obviously related. I speak from experience. My body-weight has changed little over fifty years, but I am very susceptible to cold, like most thin people.

While it is impossible to state that futile cycles, whether in BAT or in other organs, play no part in the disposal of excess dietary energy, there is good evidence that in many people they do not operate much of the time and (when they do) only on a small scale. This comes from measurements of metabolic rates in subjects who have been overfed deliberately. The immediate metabolic effect of food, known as the specific dynamic action of food or dietary thermogenesis, two equally unsatisfactory terms, is notoriously unpredictable, but in general is related to the size of the meal. It has not been shown to be substantially greater in thin people than in those with a tendency to obesity. The effect is due to increased energy utilization arising from the digestion, absorption and disposal of nutrients. If it were a regulatory function disposing of excess dietary energy, it would be expected to continue in the postabsorptive state. This does not happen-at least to a statistically significant extent. The best studies of the basal metabolic rate (also known as the resting or standard metabolic rate; SMR) on overfed subjects have been carried out in Edinburgh (Strong et al. 1967) and in Cambridge (Dauncey, 1980). In each study there were eight subjects. The mean value for the SMR in the overfed state was $I \cdot 02$ times the control value in our subjects and $I \cdot I 0$ in Dauncey's. Only one of our subjects showed a rise that we should regard as outside the error of measurement and two of her subjects showed no rise. The labour involved in both these careful studies was immense and yet sixteen subjects are not enough to draw firm quantitative conclusions. However, it can be said that in at least half of the subjects, there appeared to be no increase in metabolic rate in response to overfeeding, and in the others the response was small. I do not deny the possibility of there being a metabolic regulatory control of the energy balance, but consider it improbable that it is as important as behaviour control. 
One can look forward to retirement from a position in a university or a research institute, because life then ceases to be constrained by time-tables and other schedules of work. I now spend more time in the excellent scientific libraries in Edinburgh than I did before retirement and I enjoy this. My appetite continues to be good and I enjoy satisfying it. But I readily become conscious of a feeling of discomfort after a day or two of sitting and reading and I go out to cultivate my potato patch or to hit a hundred golf balls on the practice ground. It is possible now to give a natural drive for physical activity, obvious in childhood, a free rein. In physiological terms this drive must arise somewhere in the central nervous system and be activated by cumulative information reaching the brain from the stores of nutrients in peripheral tissues. The nature of these signals and how they vary in strength from day to day is a mystery and a challenge for investigation.

In early childhood we eat and play naturally, each in very varying amounts on different days. I guess that play with its physical activity, rather than appetite with consequent food intake is the control that regulates energy balance. In other words, in childhood we eat and then play, rather than play and then eat. In adult life work, nowadays mainly sedentary, obstructs a rhythm of life, and over the years a natural drive to physical activity may atrophy. But there are some of us who are fortunate in that this does not happen. I have always enjoyed the company of another thin man, Professor McCance, who eats well and whose energy balance I have helped to measure (McCance et al. 197I). When together we would never think of asking the questions, 'shall we take the lift' or 'catch a bus?' We just walk.

\section{REFERENCES}

Dauncey, M. J. (I 980). Br. F. Nutr. 43, 257.

Durnin, J. V. G. A. (196r). F. Physiol., Lond. r56, 294.

Food and Agricultural Organisation (1957). Calorie Requirements. FAO Nutritional Studies No. I 5 .

Garry, R. C., Passmore, R., Warnock, G. M. \& Durnin, J. V. G. A. (1955). Spec. Rep. Ser. Med. Res. Coun. Lond. No. 289.

McCance, R. A. et al. (1971). Phil. Trans. R. Soc. Lond. B, 259, 533.

Lehmann, G., Müller, E. A. \& Spitzer, H. (1950). Arbeitsphysiologie 14, 166.

Lusk, G. (1906). Science of Nutrition. Philadelphia: Saunders.

Passmore, R., Thompson, J. G. \& Warnock, G. M. (I952). Br. F. Nutr. 6, 253.

Strong, J. A., Shirling, D. \& Passmore, R. (1967). Br. F. Nutr. 12, $10_{5}$.

Taggart, N. (1962). Br. J. Nutr. 16, 223.

Widdowson, E. M., Edholm, O. G. \& McCance, R. A. (1954). Br. F. Nutr. 8, 447 .

Wilder, R. M. (1959). Archs int. Med. 103, 146. 